\title{
Determination of the Clustering Potential of the Machine- Building Industry in Zaporizhzhia Region
}

\author{
Tetiana Pulina ${ }^{1}$, Nadiia Shmygol ${ }^{1 *}$, Nikolai Somych ${ }^{2}$, Oleksii Narivs'kyi ${ }^{1}$ and Peter Gudz ${ }^{1}$ \\ ${ }^{1}$ National University «Zaporizhzhia Polytechnic», 64 Zhukovsky street, Zaporizhzhia, 69600, Ukraine \\ 2 Poltava State Agrarian Academy 1/3 Skovorody str., Poltava, 36003, Ukraine
}

\begin{abstract}
The possibilities of creating cluster associations of enterprises in the sub-branches of the Machine Building Industry in the Zaporizhzhia region by determining the clustering potential are considered. The potential of clustering of the engineering industry enterprises of the Zaporizhzhia region was assessed by using the localization coefficients, production per person and specialization of the industries. According to the results of the assessment of the clustering potential of the machine-building industry in Zaporizhzhia there are such five sub-sectors were identified in which the creation of clusters is possible: the production of computers, electronic and optical products, the production of electrical equipment, the production of machinery and equipment that are not assigned to other groupings, the production of motor vehicles, trailers and semi-trailers and other vehicles, the production of furniture and other products; repair and installation of machinery and equipment. It is proved the need to create a electric equipment production cluster in Zaporizhzhia region.
\end{abstract}

\section{Introduction}

The strategic goal of developing machine-building industry enterprises in Zaporizhzhia region is to form a structure that would meet the existing natural resource and production potential, as well as ensure the competitiveness of final products.

The engineering industry in 2018 included 208 enterprises. The volume of their production amounted to $2,8435.7$ million. or $13.0 \%$ of the total industrial production in the region and $14.0 \%$ of the volume of the machine-biulding industry in Ukraine. As of January 1, 2019, foreign investors ' funds in the machine-building industry amounted to UAH 117.23 million., or $28.1 \%$ of the total amount of foreign investment in Zaporizhzhia region.

Mechanical engineering is a knowledge-based sector of the economy, the financial condition of which largely depends on the state level of industrial development. The machine-building industry plays a significant role in the formation of the most important macroeconomic indicators of the region.

But industry enterprises are characterized by a imbalance between the availability of production capacities and real production volumes, which negatively affects the results of production activities. At the same time, the aging process of the equipment is constantly progressing. In addition, the deterioration of the financial and economic condition at most enterprises of the industry occurred due to the lack of a production structure optimized for real production volumes and product nomenclature, the deterioration of production capacities, and the discrepancy between the number of workers and real production volumes. High level of depreciation deductions, competition from the side of imported products. Therefore, the machine-building industry requires a radical restructuring. An achieving the strategic goal of the development of machinebuilding enterprises in Zaporizhzhia region is possible only if the leading sectors of the machine-building industry will be clustered.

\section{Actual scientific researches and issues analysis and the research objective}

A number of scientific works of domestic and foreign scientists and researchers are devoted to the study of determining the potential of clustering industries in individual countries $[1-3,11-25]$. . To determine the clustering potential, Vinokurova M.V., Honcharova, K.V., Ermishina, A.V., Turganbaev, E.M. etc. propose to apply coefficients of localization, production per person and specialization of industries that are widely used in the regional economy. Yermisina A.V. and Kozlova M.V. recommend analyzing statistical indicators to determine the competitiveness of the industry. Turganbaev E.M recommends to use national tables «costs-production» for indentification industrial clasters. [1-4]. But the analysis of research of the problem of determining the clustering potentials of industries in different countries revealed the lack of a methodically based approach to determining the clustering potential of an individual industry, which determines the need and relevance of stusying the problem. So the task statement is determination of the

\footnotetext{
* Corresponding author: nadezdash@ua.fm
} 
clustering potential of the Machine-Building Industry in Zaporizhzhia region and its individual sub-sectors.

\section{The possibility of creating cluster associations in the sub-sectors of the Machine-Building Industry in Zaporizhzhia region}

Let's consider the possibilities of creating cluster associations in the sub-sectors of the Machine-Building Industry of Zaporizhzhia region by determining the potential for clustering the machine-building industry of Zaporizhzhia region and its individual sub-sectors.

The potential of clustering existence is the availability of competitive advantages of industries, enterprises, infrastructure organizations located in the region and the possibility of combining and using these advantages to increase the competitiveness of the region. Currently, a unified methodology for determining the evaluation of clustering potential has not been developed. To determine the clustering potential of the machine-building industry of Zaporizhzhia region, we will use the method of N.V. Vinokurova [1], which consists in calculating the coefficients of localization, production per person and specialization of industries. If the calculated coefficients are close or more than one and tend to grow, then clusters in these industries can be created.

Table 1 shows statistics to determine the clustering potential of the machine-building industry of Zaporizhzhia region [5-8].

We will determine the localization coefficient $\left(C_{L}\right)$ of the machine-building industry of Zaporizhzhia region. The localization coefficient determines the localization (concentration) of production in the region, the level of the industry development in the region, its significance for the region's economy.

The localization coefficient of this production in the region is the ratio of the specific gravity of this sector of the economy in the structure of production in the region to the specific gravity of the same sector in the structure of production in the country.

The localization coefficient of the machine-building industry of Zaporizhzhia region is calculated by using the formula (1):

$$
\mathrm{C}_{\mathrm{L}}=\frac{V M E P_{z}}{V I P_{Z}} * 100: \frac{V M E P_{U}}{V I P_{Z}} * 100
$$

Table 1 Statistical data to determine the clustering potential of Zaporizhzhia region engineering industry 2016 2018, in million UAN

\begin{tabular}{|c|c|c|c|}
\hline Indicators & $\begin{array}{l}2016 \\
\text { year }\end{array}$ & $\begin{array}{l}2017 \\
\text { year }\end{array}$ & $\begin{array}{l}2018 \\
\text { year }\end{array}$ \\
\hline \multicolumn{4}{|l|}{ UKRAINE } \\
\hline $\begin{array}{llr}\text { Total volume } & \text { of } \\
\text { industrial products } & \text { sold, } \\
\text { million UAH }\end{array}$ & 2158030 & $\begin{array}{l}2625862, \\
7\end{array}$ & 3045202 \\
\hline
\end{tabular}

\begin{tabular}{|c|c|c|c|}
\hline Engineering & 131352 & $\begin{array}{l}168281, \\
9\end{array}$ & 207204 \\
\hline $\begin{array}{l}\text { production of computers, } \\
\text { electronic and optical } \\
\text { products }\end{array}$ & 12366,1 & 13783,3 & 16975,2 \\
\hline $\begin{array}{l}\text { production of electrical } \\
\text { equipment }\end{array}$ & 26594,6 & 32986,9 & 43098,9 \\
\hline $\begin{array}{l}\text { production of machinery } \\
\text { and equipment not } \\
\text { classified in other } \\
\text { groupings }\end{array}$ & 50105,3 & 59767,7 & 70237,3 \\
\hline $\begin{array}{l}\text { production of motor } \\
\text { vehicles, trailers and } \\
\text { semi-trailers and other } \\
\text { vehicles }\end{array}$ & 42285,8 & 61744,0 & 78365,0 \\
\hline $\begin{array}{l}\text { production of furniture } \\
\text { and other products; repair } \\
\text { and installation of } \\
\text { machines and equipment }\end{array}$ & 43650,3 & 56383,9 & 67706,2 \\
\hline $\begin{array}{l}\text { The number of permanent } \\
\text { population (at the end of } \\
\text { the year) of Ukraine, } \\
\text { million people. }\end{array}$ & 42,5 & 42,4 & 42,2 \\
\hline $\begin{array}{l}\text { Gross domestic product } \\
\text { (in actual prices), UAH } \\
\text { million }\end{array}$ & 2385367 & 2983882 & 3560596 \\
\hline \multicolumn{4}{|l|}{ Zaporizhzhia region } \\
\hline $\begin{array}{l}\text { Total volume of } \\
\text { industrial products sold, } \\
\text { million UAH }\end{array}$ & 152863 & $\begin{array}{l}197567, \\
8\end{array}$ & 220108 \\
\hline Engineering & 18214,8 & 26390 & 28435,7 \\
\hline $\begin{array}{l}\text { production of computers, } \\
\text { electronic and optical } \\
\text { products }\end{array}$ & 1580,2 & 1013,8 & 1523,8 \\
\hline $\begin{array}{l}\text { production of electrical } \\
\text { equipment }\end{array}$ & 6003,7 & 7624,5 & 10537 \\
\hline $\begin{array}{l}\text { production of machinery } \\
\text { and equipment not } \\
\text { classified in other } \\
\text { groupings }\end{array}$ & 3048,7 & 4183,4 & 4597,6 \\
\hline $\begin{array}{l}\text { production of motor } \\
\text { vehicles, trailers and } \\
\text { semi-trailers and other } \\
\text { vehicles }\end{array}$ & 7582 & 13568,3 & 11777,1 \\
\hline $\begin{array}{l}\text { production of furniture } \\
\text { and other products; repair } \\
\text { and installation of } \\
\text { machines and equipment }\end{array}$ & 5721,9 & 5203,5 & 4432,7 \\
\hline $\begin{array}{l}\text { Resident population } \\
\text { (annual average), million }\end{array}$ & 1,75 & 1,73 & 1,72 \\
\hline $\begin{array}{l}\text { Gross regional product, } \\
\text { UAH million }\end{array}$ & 104323 & 130377 & 147076 \\
\hline
\end{tabular}

where: $V M E R_{Z}$ is the volume of mechanical engineering products sold in Zaporizhzhia region, million UAH;

$V I P_{Z}$ - the volume of sold industrial products in Zaporizhzhia region, million $\mathrm{UAH}$; 
$V M E R_{U}$ - volume of engineering products sold in Ukraine, million UAH;

$V I P_{U}$ - volume of sold industrial products in Ukraine, million UAH

Table 2 shows calculations of localization coefficient of the machine-building industry of Zaporizhzhia region [5-8].

Table 2 Calculations of localization coefficient of Zaporizhzhia region engineering industry

\begin{tabular}{|c|c|c|c|}
\hline \multirow{2}{*}{ Indicators } & \multicolumn{2}{|c|}{ Years } \\
\cline { 2 - 4 } & $\mathbf{2 0 1 6}$ & $\mathbf{2 0 1 7}$ & $\mathbf{2 0 1 8}$ \\
\hline$\frac{V M E P_{z}}{V I P_{Z}}$ & 0,119 & 0,134 & 0,129 \\
\hline$\frac{V M E P_{U}}{V I P_{Z}}$ & 0,061 & 0,064 & 0,060 \\
\hline $\begin{array}{c}\text { Localization } \\
\text { coefficient }\end{array}$ & 1,95 & 2,09 & 2,15 \\
\hline
\end{tabular}

For three years the average indicator of the localization coefficient of enterprises of the machinebuilding industry in Zaporizhzhia region was 1.99. This is good indicator to create a cluster.

The per capita production coefficient $\left({ }^{C_{p p}}\right)$ is calculated as the ratio of the specific gravity of the economic activity of the region in the corresponding structure of the economic activity of the country to the specific gravity of the region population of the population in the country according to the formula (2):

$$
\mathrm{C}_{\mathrm{pp}}=\frac{V M E P_{z}}{V M E P_{U}} * 100: \frac{P_{r}}{P_{c}} * 100 ;
$$

where: $V M E P_{Z}$ is the volume of mechanical engineering products sold in Zaporizhzhia region, million UAH;

$V M E P_{U}$ - volume of engineering products sold in Ukraine, million UAH;

$P_{R}$ - the population of the region;
$P_{c}$ - the population of the country.

Table 3 shows calculations of per capita production coefficient of the machine-building industry of Zaporizhzhia region [5-8].

The average value of the per capita production coefficient was 3.66 for three years which indicates the possibility of creating clusters.

Table 3 Calculation of per capita production coefficient of the machine-building industry in Zaporizhzhia region for 2016-2018

\begin{tabular}{|l|c|c|c|}
\hline \multirow{2}{*}{ Indicators } & \multicolumn{3}{|c|}{ Years } \\
\cline { 2 - 4 } & $\mathbf{2 0 1 6}$ & $\mathbf{2 0 1 7}$ & $\mathbf{2 0 1 8}$ \\
\hline
\end{tabular}

\begin{tabular}{|c|c|c|c|}
\hline$\frac{V M E P_{z}}{V M E P_{U}}$ & 0,139 & 0,159 & 0,141 \\
\hline$\frac{P_{r}}{P_{c}}$ & 0,041 & 0,041 & 0,041 \\
\hline $\begin{array}{l}\text { Per capita } \\
\text { production } \\
\text { coefficient }\end{array}$ & 3,39 & 3,87 & 3,43 \\
\hline
\end{tabular}

The coefficient of specialization $\left(C_{s}\right)$ is defined as the ratio of the specific gravity of the region in the country for this type of economic activity to the specific gravity of the region in the country's GDP (3):

$$
\mathrm{C}_{\mathrm{s}}=\frac{V M E P_{z}}{V M E P_{U}} * 100: \frac{G R P}{G D P} * 100
$$

where $V M E P_{Z}$ is the volume of mechanical engineering products sold in Zaporizhzhia region, million UAH;

$V M E P_{U}$ - volume of engineering products sold in Ukraine, million UAH;

GRP - gross regional product UAH;

GDP is gross domestic product UAH.

Table 4 shows calculations of the specialization coefficient of Zaporizhzhia region engineering industry [5-8].

Table 4 Calculation of specialization coefficient of enterprises of the machine-building industry in Zaporizhzhia region.

\begin{tabular}{|c|c|c|c|}
\hline \multirow{2}{*}{ Indicators } & \multicolumn{2}{|c|}{ Years } \\
\cline { 2 - 4 } & 2016 & 2017 & 2018 \\
\hline$\frac{V M E P_{z}}{V M E P_{U}}$ & 0,139 & 0,159 & 0,141 \\
\hline GRP/GDP & 0,044 & 0,044 & 0,044 \\
\hline $\begin{array}{l}\text { specialization } \\
\text { coefficient }\end{array}$ & 3,15 & 3,61 & 3,20 \\
\hline
\end{tabular}

The average value of the specialization coefficient has been 2.98 for three years which indicates the possibility of creating clusters.

Integral coefficient of clustering potential is determined by formula (4):

$$
\mathrm{C}_{\mathrm{kl}}=\sqrt[3]{C_{l} * C_{p p} * C_{s}},
$$

The integral clustering potential coefficient allows us to evaluate the industry's prospects for creating cluster associations of the enterprises (table 5)

Table 5 Integral coefficient of clustering potential

\begin{tabular}{|c|c|c|c|}
\hline \multirow{2}{*}{ Indicators } & \multicolumn{3}{|c|}{ Years } \\
\cline { 2 - 4 } & 2016 & 2017 & 2018 \\
\hline $\begin{array}{c}\text { Localization } \\
\text { coefficient }\end{array}$ & 1,83 & 2,16 & 2 \\
\hline
\end{tabular}




\begin{tabular}{|c|c|c|c|}
\hline $\begin{array}{c}\text { Specialization } \\
\text { coefficient }\end{array}$ & 3,5 & 4 & 3,5 \\
\hline $\begin{array}{c}\text { Per capita production } \\
\text { coefficient }\end{array}$ & 3,5 & 4 & 3,5 \\
\hline $\begin{array}{c}\text { Integral coefficient of } \\
\text { clustering potential }\end{array}$ & 2.94 & 3,39 & 3,0 \\
\hline
\end{tabular}

The average value of the integral clustering potential coefficient was 3.11 for three years, which indicates the possibility of creating clusters.

Thus, we can conclude that the machine-building industry of Zaporizhzhia region has a clustering potential sufficient to create clusters. To calculate the coefficient of localization for the sub-branches of Zaporizhzhia region engineering industry, we will consider the volume of sold products in the production of engineering for 2016-2018 in Ukraine and Zaporizhzhia region.

Table 6 shows calculated production localization factors for sub-sectors of the machine-building industry of Zaporizhzhia region.

Table 6 Calculation of localization coefficient for enterprises of the machine-building industry of Zaporizhzhia region

\begin{tabular}{|l|c|c|c|}
\hline \multirow{2}{*}{\multicolumn{1}{|c|}{ Indicators }} & \multicolumn{2}{|c|}{ Years } \\
\cline { 2 - 4 } & $\mathbf{2 0 1 6}$ & $\mathbf{2 0 1 7}$ & $\mathbf{2 0 1 8}$ \\
\hline Engineering & 1,83 & 2,16 & 2 \\
\hline $\begin{array}{l}\text { production of computers, } \\
\text { electronic and optical } \\
\text { products }\end{array}$ & 1,56 & 1,97 & 1,56 \\
\hline $\begin{array}{l}\text { production of electrical } \\
\text { equipment }\end{array}$ & 1,31 & 3,07 & 1,78 \\
\hline $\begin{array}{l}\text { production of machinery and } \\
\text { equipment not classified in } \\
\text { other groupings }\end{array}$ & 1,16 & 1,68 & 1,41 \\
\hline $\begin{array}{l}\text { production of motor vehicles, } \\
\text { trailers and semi-trailers and } \\
\text { other vehicles }\end{array}$ & 1,39 & 2,92 & 1,94 \\
\hline $\begin{array}{l}\text { production of furniture and } \\
\text { other products; repair and } \\
\text { installation of machines and } \\
\text { equipment }\end{array}$ & 1,85 & 1,22 & 1,41 \\
\hline
\end{tabular}

Table 7 shows calculated per capita production coefficient for the sub-sectors of the machine-building industry of Zaporizhzhia region.

Table 7 Per capita production coefficient of sub-branches of the machine-building industry in Zaporizhzhia region

\begin{tabular}{|l|c|c|c|}
\hline \multirow{2}{*}{\multicolumn{1}{|c|}{ Indicators }} & \multicolumn{3}{|c|}{ Years } \\
\cline { 2 - 4 } & 2016 & 2017 & 2018 \\
\hline Engineering & 3,5 & 4 & 3,5 \\
\hline $\begin{array}{l}\text { production of computers, } \\
\text { electronic and optical } \\
\text { products }\end{array}$ & 1,31 & 1,8 & 1,17 \\
\hline $\begin{array}{l}\text { production of electrical } \\
\text { equipment }\end{array}$ & 5,48 & 5,6 & 3,63 \\
\hline
\end{tabular}

\begin{tabular}{|l|c|c|c|}
\hline $\begin{array}{l}\text { production of machinery } \\
\text { and equipment not } \\
\text { classified in other groupings }\end{array}$ & 1,47 & 1,64 & 1,42 \\
\hline $\begin{array}{l}\text { production of motor } \\
\text { vehicles, trailers and semi- } \\
\text { trailers and other vehicles }\end{array}$ & 4,35 & 5,32 & 3,64 \\
\hline $\begin{array}{l}\text { production of furniture and } \\
\text { other products; repair and } \\
\text { installation of machines and } \\
\text { equipment }\end{array}$ & 3,18 & 2,23 & 1,58 \\
\hline
\end{tabular}

Table 8 shows the calculated coefficients of specialization of production for sub-sectors of the metallurgical industry of Zaporizhzhia region.

Table 8 Specialization coefficient for sub-sectors machine-building industry of Zaporizhzhia region

\begin{tabular}{|l|c|c|c|}
\hline \multirow{2}{*}{ Indicators } & \multicolumn{2}{|c|}{ Years } \\
\cline { 2 - 4 } & 2016 & 2017 & 2018 \\
\hline Engineering & 3,5 & 4,0 & 3,5 \\
\hline $\begin{array}{l}\text { production of computers, } \\
\text { electronic and optical } \\
\text { products }\end{array}$ & 2,92 & 1,68 & 2,17 \\
\hline $\begin{array}{l}\text { production of electrical } \\
\text { equipment }\end{array}$ & 5,16 & 5,25 & 5,91 \\
\hline $\begin{array}{l}\text { production of machinery } \\
\text { and equipment not } \\
\text { classified in other groupings }\end{array}$ & 1,39 & 1,6 & 1,58 \\
\hline $\begin{array}{l}\text { production of motor } \\
\text { vehicles, trailers and semi- } \\
\text { trailers and other vehicles }\end{array}$ & 4,09 & 5,02 & 3,63 \\
\hline $\begin{array}{l}\text { production of furniture and } \\
\text { other products; repair and } \\
\text { installation of machines and } \\
\text { equipment }\end{array}$ & 2,99 & 2,11 & 1,58 \\
\hline
\end{tabular}

Table 9 shows integral coefficient of clustering potential for Zaporizhzhia region engineering industry sub-sectors.

Table 9 Specialization coefficient for sub-sectors engineering industry of Zaporizhzhia region

\begin{tabular}{|l|c|c|c|}
\hline \multirow{2}{*}{ Indicators } & \multicolumn{2}{|c|}{ Years } \\
\cline { 2 - 4 } & 2016 & 2017 & 2018 \\
\hline Engineering & 2.94 & 3,39 & 3,0 \\
\hline $\begin{array}{l}\text { production of computers, } \\
\text { electronic and optical } \\
\text { products }\end{array}$ & 1,93 & 1,82 & 1,63 \\
\hline $\begin{array}{l}\text { production of electrical } \\
\text { equipment }\end{array}$ & 3,98 & 4,64 & 3,77 \\
\hline $\begin{array}{l}\text { production of machinery } \\
\text { and equipment not } \\
\text { classified in other } \\
\text { groupings }\end{array}$ & 1,34 & 1,64 & 1,47 \\
\hline $\begin{array}{l}\text { production of motor } \\
\text { vehicles, trailers and } \\
\text { semi-trailers and other } \\
\text { vehicles }\end{array}$ & 3,28 & 4,42 & 3,07 \\
\hline
\end{tabular}




\begin{tabular}{|l|l|l|l|}
\hline $\begin{array}{l}\text { production of furniture } \\
\text { and other products; repair } \\
\text { and installation of } \\
\text { machines and equipment }\end{array}$ & 2,99 & 2,47 & 1,52 \\
\hline
\end{tabular}

After analyzing the data of tables 5,6,7,9 it can be seen that the localization coefficients, per capita production coefficient, specialization coefficients, integral coefficient of clustering potential of the five sub-sectors of the Zaporizhzhia region engineering industry are more than one. And in the sub-sector of electrical equipment production, these determined coefficients are the highest.

It is proposed to create a cluster association of enterprises in the sub-sector of the electrical equipment production. We consider it expedient to include such regional enterprises of energy engineering to this cluster, nameles: «Zaporizhtransformator» PJSC, «MGT» PJSC, «Zaporizhzhia superpower transformers plant» PJSC, SE "SPC "Iskra", «ZZVA» PJSC, «Zaporizhzhia plant «Preobrazovatel» PJSC, "Motor Sich" PJSC, SE «Ivchenko-Progress», SIA "RENKO".

It should be noted that "Zaporozhtransformator» PJSC is the largest specialized enterprise of world transformer building and carries out development, supply and service maintenance of the entire range of oil, dry power and general purpose distribution transformers, special transformers, components for them (cooling plants, voltage regulators, etc.), higt amperes current conductor of closed type.

«MGT» PJSC produces distribution transformers with a capacity of up to $1000 \mathrm{kVA}$ and power transformers with a capacity of 10-1000 kVA.

«Zaporizhzhia superpower transformers plant» PJSC specializes in the manufacture of power dry and oil transformers, as well as in the repair of transformers of all types.

Thus, the involvement of these enterprises in the energy engineering cluster will make it possible to carry out a comprehensive replacement of the outdated transformer fleet of the energy sector within the Zaporizhzhia region.

The need to participate in the cluster project of «ZZVA» PJSC is due to the fact that the enterprise is a producer of products that ensure the transmission of electricity, especially over long distances, and its distribution to end users.

The usefulness of in involving "Zaporizhzhia plant Preobrazovatel" PJSC to the cluster is due to the fact that the company is a manufacturer of power electronics that are able to regulate and convert energy from one type to another, optimal. The need to use power electronics is due to the fact that the use of electricity in the form in which it is produced, that is, in the form of alternating current with a frequency of $50 \mathrm{~Hz}$ or impossible under the conditions of some technologies.

Thus, the use of modern products of "Zaporizhzhia plant Preobrazovatel" PJSC will make it possible to turn the generated electricity into the state that specific consumers need, meet various technological needs while reducing its losses.
State Enterprise "Scientific and Production Complex "Iskra" is a leading developer and manufacturer of ground-based radar technology for Ukraine's defense industry. The Complex includes a Design Bureau and a Engineering Plant.

In addition, we consider it necessary to also include in the cluster of "Motor Sich" PJSC which is capable of producing cogeneration stations. The use of cogeneration plants on the basis of heating boilers can increase the efficiency of fuel use to $90-92 \%$, because the additional equipment of boiler houses with electric power generation modules allows without increasing gas costs for heat production to receive "as a gift" electricity for an amount that corresponds to the cost of about $20 \%$ of the spent fuel.

Thus, the involvement of «Motor Sich» PJSC in the energy engineering cluster will allow to introduce energy-saving technologies in the sector of urban heating plants with the prospect of obtaining additional income from an increase in electricity production in the region.

Note that «Motor Sich» PJSC has the ability not only to produce cogeneration stations, but also with the help of SE "Ivchenko-Progress" to develop various modifications of cogeneration plants to fully meet the needs of various consumers. In addition, the production capacity of «Motor Sich» PJSC is currently loaded by only $25-30 \%$, which creates significant opportunities for the perspective growth of the enterprise and increase its share in the domestic market, which today accounts for no more than $5 \%$ of the total supply of «Motor Sich» PJSC.

SIA "RENKO" Scientific and Industrial Association was the first to present an energy efficiency program in Zaporizhzhia region [9]. The main focus of the program is the consistent introduction of energy-saving technologies in the residential sector and the municipal sector of the region; estimated amount of capital attraction 100-130 million UAH per year. One of the areas of implementation of this program is the construction of a network of cogeneration stations with a total capacity of up to 5 thousand. MW (capacity of one - 3.4 MW).

The implementation of this direction will contribute to improving the efficiency of the power system due to the creation of a competitive conditions in the field of thermal and electric energy generation.

Note that we consider it necessary to include in the proposed regional cluster enterprises that are transfed and distributed the electric energy, which will act as end users of the cluster's products, primarily «Zaporozheoblenergo» PJSC.

It should be noted to increase innovation, regional research institutes can play an active role in the cluster. It is these institutions, which have significant potential, but are not enough in demand under the conditions of the domestic present, that can act as a catalyst for the innovative development of cluster association [10].

Involvement in cooperation within the cluster of specialized scientific institutions will make it possible to intensify research and design work in the direction of 
creating innovations (development of new technologies, improvement of technological processes, etc.), as well as will contribute to accelerating the pace of implementation of research results at enterprises, which will have a positive impact on the processes of design and production of new types of products by cluster participants.

This interaction within the cluster will make it possible to establish a close connection in the chain "science - industry (production complex) - market." We note that the ability to develop and use innovative technologies is one of the most important factors in strengthening the position of the cluster. In addition, the nearby enterprises and institutions within the project will contribute to the accelerated exchange of existing knowledge, experience, ideas, developments and strengthening of production cooperation.

Specialized scientific institutions in the field of mechanical engineering such as «Zaporizhzhia plant «Preobrazovatel» PJSC, SE «Ivchenko-Progress», «AllUkrainian» Institute of Transformer Engineering» PJSC should be involved in the energy engineering cluster.

The involvement of scientific institutions will make it possible to intensify activities in such areas as the development of new technologies, research, innovation, the generation of ideas, the development of new products ordered by cluster members, as well as to ensure the optimal combination of existing production capacities and the modern base of scientific research and development.

To increase the efficiency of the cluster, we also propose to involve the educational sector in cooperation, primarily Zaporizhzhia Polytechnic National University, Zaporizhzhia National University (ZNU), which have practical experience in training specialists in the field of mechanical engineering (including electrical engineering), energy and energy saving. Higher education institutions have the opportunity to provide training on orders of project participants; develop and implement special training, retraining and development programmes, etc. This will create additional opportunities to receive profit from the orders of cluster members. It is also possible for students to carry out scientific, thesis and term papers in areas that are most interested for enterprises, as well as carry out scientific research ordered by entrepreneurs. In turn, cluster enterprises will become a good practice base for students with the provision of the necessary materials for student research and perspective employment opportunities.

The involvement of regional banks in the financial sector cluster project will provide additional financial resources for the cluster to perform its tasks. In addition, regional banks can get several positive effects from participating in the project:

- Strengthening its own position in the conditigons of increased competition in attracting and servicing accounts of new customers (especially large industrial enterprises);
- the possibility of increasing financial resources, obtaining significant profits by increasing operations and the client base;

- the possibility of obtaining income from direct participation of cluster activities.

As part of a single cluster program, the participating bank will be able to manage most of the financial resources of the cluster and profit not only from lending to members of the association, but also from managing its financial flows, thus acting not only as a source of financing, but also as a financial operator of the cluster.

An important role in the implementation of the cluster project in the region should also be played by state and non-state public organizations, which can provide legal support for the relations of project participants, help in attracting additional sources of financing, deal with the distribution of risks, provide information and educational services, contribute to a significant dissemination of information about cluster projects, etc.

Therefore, in the field of production, we can expect the development of fundamentally new types of products, especially taking into account the needs of domestic consumers, increasing the specialization of production, reducing the production cycle of production due to the interaction of participants, and increasing the requirements for the quality of cluster products.

The main areas of development of the association in the production and technical and technological spheres include:

- increasing of the range of produced products;

- improving the quality, reliability and convenience of maintenance;

- creation of new constructions, equipment for the needs of domestic energy and industry;

- improvement of existing constructions with the aim of technical improvement of their parameters, namely reduction of material consumption, labour intensity and losses based on introduction of new technological solutions;

- meeting the requirements of international and national standards for products, meeting the specific needs of customers.

In the non-production sphere, we can expect the development of partnerships, the development of new interaction schemes, deepening cooperation between enterprises, increasing the availability of information, which will increase the cost of joint research and development, the introduction of new technologies for managing production and sales processes, financial processes, improving the quality of business processes, and developing cluster infrastructure.

At the same time, we believe that the specialization of the cluster is an important factor that will contribute to the most effective manifestation of cooperative communication within the association. The formation of a unified cluster association management system will facilitate the coordination and integration of management activities of individual participants into a single complex. This will ensure a more flexible and rapid response of the cluster to changes in the internal 
environment, which means that it will improve its competitive position.

In addition, the intensification of information flows within the cluster will contribute to the accelerated dissemination of existing knowledge and technical innovations, which can be considered as an important competitive advantage of the cluster. We emphasize that these facts will help improve the position of both the joint cluster brand and the perspective self-development of individual member brands.

It should be noted that cooperation within the cluster of scientific and business sectors will contribute in the future to the reorganization of scientific institutions in the direction of increasing scientific research for specific purposes, first of all, to meeting the current and promising needs of various groups of potential clients of the cluster.

\section{The structure of the power engineering cluster of Zaporizhzhia region}

A more specific structure of the energy engineering cluster of in the Zaporizhzhia region is pointed out in Figure 1.

In general, within the existing cluster, it is possible to expect an improving of the competitive position of its participants due to an increase in their share in the domestic market (expansion of the consumer base of cluster products), as well as the opportunity to offer consumers an updated nomenclature and a wider range of products, compared to the assortment of individual participants to cluster.

We emphasize that one of the consequences of the effective work of the proposed cluster may be an increase in the cost of cluster enterprises and an increase in capitalization, which, in turn, will contribute to increasing the investment attractiveness of both enterprises alone and the association as a whole.

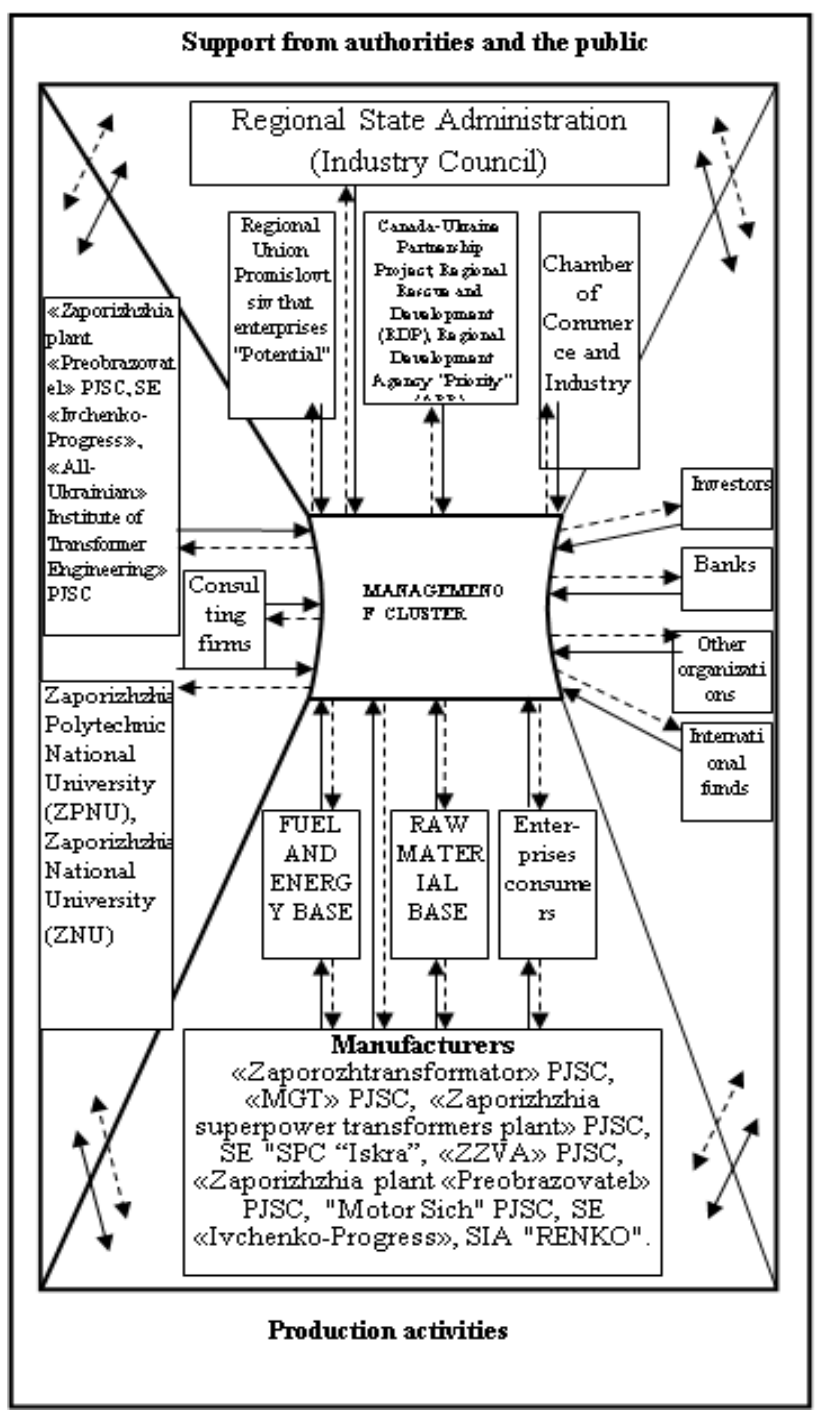

Fig. 1. The cluster structure based on electric equipment production in Zaporizhzhia region.

Due to the scale of the association, it is also possible to enter directly the international financial level (international banks, exchanges, insurance companies, funds, etc.) in order to place their own shares and obtain the necessary investment resources.

\section{Conclusions}

Based on the results of the study, a significant potential was identified for the creation of cluster associations of enterprises of the machine-building industry of Zaporozhye region, the assessment of which was carried out using coefficients of localization, production per person and specialization of industries. According to the results of the assessment of the clustering potential of the machine-building industry of Zaporozhye region, five sub-sectors in which the creation of clusters is possible have been identified. namely, the production of computers, electronic and optical products, the production of electrical equipment, the production of machinery and equipment not classified elsewhere, the production of motor vehicles, trailers and semi-trailers and other vehicles, the production of furniture and other 
products; repair and installation of machinery and equipment Proved the need to create a cluster of electrical equipment production in Zaporizhzhia region.

It was found necessary to intensify innovation and transition to an innovative development model. The cluster development strategy is substantiated by the innovation strategy model of Zaporizhzhia region's industrial complex.

\section{References}

1. Vinokurova M.V. (2006), "Competitiveness and clustering potential of industries in the Irkutsk region", Jeko., vol. 12, pp. 73-93. Russia.

2. Honcharova, K.V. (2009), "Improving the methodology for determining the clustering potential of industries in a particular region", Ekonomichnyj prostir: Zbirnyk naukovykh prats', $P D A B A$, vol. 29, pp. 80-88.

3. Crmishina, A.V. (2002), "Competitiveness of the region", Strategii, vol. 1, pp. 116-118.

4. Turganbaev, E.M., Kozlova, E.M. (2009), "Identification of regional industrial clusters and assessment of their structural impact on the region's economy (on the example of EKO)", Upravlenie bol'shimi sistemami, vol. 25, pp. 139-178.

5. Statistical Yearbook of Ukraine (2018), in. Vernera, I. Ye (ed.), Konsul'tant, Kiev, Ukraine.

6. Official site of Derzhkomstat, [Online], available at: http://www.ukrstat.gov.ua. / (Accessed 9 January 2021), (In Ukrainian).

7. Statistical Yearbook of Zaporizhia region (2018), Main Department of Statistics in Zaporizhia region, in. Shejko M. (ed.), Zaporozhye, Ukraine.

8. Official site of the main department of statistics in the Zaporozhye region [Online], available at: http://zp.ukrstat.gov.ua/ (Accessed 9 January 2021).

9. Nadiia Shmygol, Olena Cherniavska, Tetiana Pulina, Ruslan Zavgorodniy (2020), "Economic assessment of the implementation of the resource-efficient strategy in the oil and gas sector of the economy on the basis of distribution of trade margins between extracting and processing enterprises", Polityka Energetyczna, Energy Policy Journal, vol. 23(3), pp. 135-146.

10. Narivs'kyi, O.E, Yar-Mukhamedova, G., Temirgaliyeva, E., Mukhtarova, M., YarMukhamedov, Y. (2016), "Corrosion losses of alloy 06XN28MDT in chloride-containing commercial waters International Multidisciplinary Scientific GeoConference Surveying Geology and Mining Ecology Management", SGEM, vol. 1, pp. 63-70.

11. Zavidna L. and other. Strategy of Innovative Development as an Element to Activate Innovative Activities of Companies. In: Academy of Strategic Management Journal, 2019.

https://www.abacademies.org/articles/strategy-of- innovative-development-as-an-element-toactivateinnovative-activities-of-companies-8385.htm

12. Shmygol, N., Galtsova, O., \& Varlamova, I. (2018). Developing a methodology to assess the environmental and economic performance index based on international research to resolve the economic and environmental problems of Ukraine. Baltic Journal of Economic Studies, 4(4), 366-374

13. Kwilinski, A., Dalevska, N., Kravchenko, S., Hroznyi, I., Kovalenko, I. (2019). Formation of the entrepreneurship model of e-business in the context of the introduction of information and communication technologies. Journal of Entrepreneurship Education, 22(1S), 1528-265122-S1-337: 1-7. Retrieved from https://www.abacademies.org/articles/Formati on-of-the-entrepreneurship-model-of-e-business1528-2651-22-S1-337.pdf

14. Mykoliuk, O., Bobrovnyk, V., Fostolovych, V., Kucherova, H., Nataliia, P. Modelling the Level of Energy Security at Enterprises in the Context of Environmentalization of Their Innovative Development. 2020 10th International Conference on Advanced Computer Information Technologies, ACIT 2020 - Proceedings, 2020, pp. 621625, 9208996

15. Kucherova, H., Pokataieva, O., Bilska, O. Modelling tax consciousness evaluation in the context of economic development uncertainty. Periodicals of Engineering and Natural Sciences, 2019, 7(2), pp. 567-579

16. Gryshko V., Zos-Kior M., Zerniuk O. Integrating the BSC and KPI systems for improving the efficiency of logistic strategy implementation in construction companies. International Journal of Engineering \&amp; Technology. Vol. 7, № 3.2. 2018. Special Issue 2. P. 131-134.

17. Zos-Kior M., Kuksa I., Samoilyk I., Storoška M. Methodology for assessing the countries' globalization development. Economic Annals-XXI. №11-12. 2017. P. 4-8.

18. Kuksa I. Adaptive accounting of production activities of transnational companies in the conditions of globalization / I. Kuksa, L. Vasyurenko, A. Litvinov, O. Lytvynova, I. Shtuler, M. Zos-Kior, O. Naholiuk. Accounting. №6.2020. P. 913-922. 